\title{
Significant Anti-Inflammatory Properties of a Copper(II) Fenoprofenate Complex Compared with its Parent Drug. Physical and Chemical Characterization of the Complex
}

\author{
Mariela A. Agotegaray, ${ }^{a}$ Mónica A. Boeris ${ }^{b}$ and Oscar V. Quinzani ${ }^{*, a}$ \\ aINQUISUR, Departamento de Química, Universidad Nacional del Sur, Avda. Alem 1253, \\ B8000CPB Bahía Blanca, Argentina \\ ${ }^{b}$ Centro de Investigación y Desarrollo de Fármacos (CIDEF), Facultad de Ciencias Veterinarias, \\ Universidad Nacional de La Pampa, Calle 5 y 116, General Pico, CP 6360, Argentina
}

\begin{abstract}
A síntese, a caracterização físico-química, as propriedades anti-inflamatórias e a atividade mimética de catecolase do complexo de cobre(II) com a droga anti-inflamatória non-esteroidal Fenoprofeno [ácido 2-(3-fenóxifenil)propiônico] com fórmula $\left[\mathrm{Cu}_{2}(\mathrm{fen})_{2}(\mathrm{dmf})_{2}\right]$ (fen = ânion do fenoprofenato, $\mathrm{dmf}=N, N$-dimetilformamida) foram investigadas. Os resultados da análise espectroscópica (espectros de FTIR e EPR) e dados de análise termogravimétrica e térmica diferencial obtidos para o complexo sólido estão de acordo com a sua estrutura dinuclear. Os espectros eletrônicos do produto são igualmente apresentados e discutidos neste trabalho. O complexo foi testado para as suas propriedades anti-inflamatórias em comparação com a droga de referência, o sal de cálcio do Fenoprofeno. A administração oral do composto binuclear inibiu o desenvolvimento do edema induzido por carragenana em ratos; esta inibição foi mais significativa do que a obtida com a droga de referência. O estudo cinético da atividade mimética da catecolase foi realizado espectrofotometricamente, monitorando-se a transformação oxidativa do 3,5-di-terc-butilcatecol na $o$-quinona correspondente. Os parâmetros cinéticos foram determinados pelo emprego do modelo de Michaelis-Menten, que demonstrou que o novo complexo mimetiza a atividade da catecol oxidase.
\end{abstract}

The synthesis, physicochemical characterization, anti-inflammatory properties and catecholase mimetic activity of the dinuclear complex of copper(II) with the non-steroidal anti-inflammatory drug Fenoprofen [2-(3-phenoxyphenyl)propionic acid] with formula $\left[\mathrm{Cu}_{2}(\mathrm{fen})_{4}(\mathrm{dmf})_{2}\right]$ (fen = fenoprofenate anion, $\mathrm{dmf}=N, N$-dimethylformamide) have been investigated. Results of spectroscopic analysis (FTIR and EPR) as well as thermogravimetric and differential thermal analysis data obtained for the solid complex are in good agreement with its dinuclear structure. Electronic spectra of the product are also reported and discussed. The complex was tested for anti-inflammatory properties in comparison to the parent drug, Fenoprofen calcium salt. Oral administration of the dinuclear compound inhibited development of carrageenan-induced oedema in mice; this inhibition was higher than that observed for the parent drug. The kinetic study of the catecholase mimetic activity was carried out spectrophotometrically by monitoring the oxidative transformation of 3,5-di-tert-butylcatechol into the corresponding light-absorbing $o$-quinone. Kinetic parameters were determined employing the Michaelis-Menten model, showing that the new complex presents catechol oxidase mimetic activity.

Keywords: copper(II), Fenoprofen, anti-inflammatory properties, catecholase activity

\section{Introduction}

The proposed curative properties of copper(II) carboxylate-based non-steroidal anti-inflammatory drugs

*e-mail: quinzani@criba.edu.ar
(NSAIDs) have led to the development of numerous mononuclear and dinuclear copper(II) complexes of NSAIDs with enhanced anti-inflammatory activity. ${ }^{1,2}$ The elevation of total blood copper levels during acute as well as chronic inflammatory states has been reported ${ }^{3}$ and is thought to proceed from the natural anti-inflammatory response of the host. ${ }^{4}$ 
An adequate intake of copper during chronic inflammatory diseases, such as rheumatoid arthritis, may influence the efficiency of the organic serum response. ${ }^{5}$ Sorenson ${ }^{6-8}$ attributed the anti-inflammatory activity to the action of the complexes in vivo due to their inherent physico-chemical properties, but Rainsford et al. ${ }^{9}$ have suggested that the activity may be due to a counter-irritant mechanism triggered by free copper ions. A number of researchers have found that some complexes show similar but not significantly greater anti-inflammatory activity. ${ }^{10,11}$

It is also known that dinuclear copper active centres play an important role in biological metalloproteins ${ }^{12-14}$ as tyrosinase, hemocyanin or catechol oxidase. Catechol oxidase (EC 1.10.3.1) is a type III copper enzyme containing a dinuclear copper centre and belongs to the polyphenol oxidases group,${ }^{15}$ which catalyses exclusively the oxidation of catechols to the corresponding $o$-quinones in the presence of oxygen. ${ }^{16,17}$ This reaction is of great importance in the oxidation of biological catechols such as dopamine and in medical diagnosis for the determination of the hormonally active catecholamines: adrenaline, noradrenaline and dopamine. ${ }^{15}$ The catecholase activity has been determined in vitro for many mononuclear and dinuclear copper(II) complexes. Specialized research groups have developed $\mu$-hidroxo, $\mu$-carboxylato or $\mu$-imidazole dinuclear copper(II) compounds with the aim of mimicking the active site of the catechol oxidase enzyme, ${ }^{12-15,18-29}$ and the mechanism of the catalytic cycle has been proposed for some complexes. Catecholase activity has been also determined for a few mononuclear and dinuclear copper(II)-NSAIDs complexes, ${ }^{30-32}$ but the mechanism of the catalytic oxidation remains unclear.

Fenoprofen, 2-(3-phenoxyphenyl)propionic acid or $\alpha$-methyl-3-phenoxybenzeneacetic acid (Scheme 1) is an antipyretic, analgesic and non steroidal anti-inflammatory drug (NSAID). It belongs to the group of compounds commonly referred as the 2 -arylpropionic acids. ${ }^{33}$<smiles>CC(C(=O)O)c1cccc(Oc2ccccc2)c1</smiles>

Scheme 1. Structure of Fenoprofen (Hfen).

Little is known about chemical structures of Fenoprofen salts and complexes. Only three crystal structures related to this compound have been reported: sodium fenoprofenate dihydrate,,$^{34}$ calcium fenoprofenate monohydrate ${ }^{35}$ and the dinuclear complex bis(dimethylformamide- $\kappa O)$ tetrakis $\{\mu$ - fenoprofenate $\left.\left(\kappa^{2} O, O^{\prime}\right)\right\} \operatorname{dicopper}(\mathrm{II}),\left[\mathrm{Cu}_{2}(\mathrm{fen})_{4}(\mathrm{dmf})_{2}\right]$, recently reported by our research group (Scheme 2$){ }^{36}$

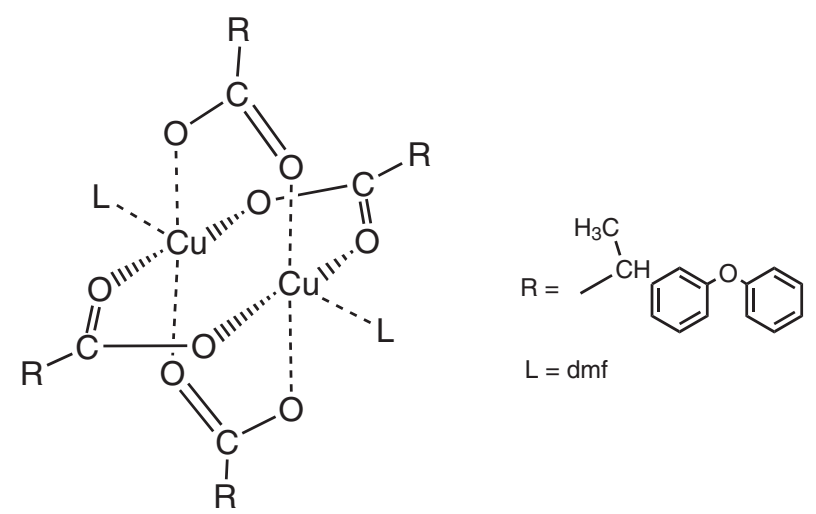

Scheme 2. Structure of the dinuclear copper complex $\left[\mathrm{Cu}_{2}(\mathrm{fen})_{4}(\mathrm{dmf})_{2}\right]$.

Because of the biological importance of dinuclear copper(II) complexes with NSAIDs and taking into account that no reports on the pharmacological properties of copper(II)-fenoprofenate complexes have been described in the literature, here we report the physical and chemical characterization of $\left[\mathrm{Cu}_{2}(\mathrm{fen})_{4}(\mathrm{dmf})_{2}\right]$ together with its antiinflammatory properties and catecholase mimetic activity.

\section{Experimental}

\section{Reagents and materials}

Fenoprofen calcium salt and 3,5-di-tert-butylcatechol were purchased from Sigma-Aldrich. All other reagents and solvents were of analytical grade and used without further purification. The experiments carried out with animals were approved by the Facultad de Ciencias Veterinarias, Universidad Nacional de La Pampa, Argentina.

\section{Synthesis of the complex}

The complex $\left[\mathrm{Cu}_{2}(\mathrm{fen})_{4}(\mathrm{dmf})_{2}\right] \cdot 2 \mathrm{H}_{2} \mathrm{O}$ was prepared according to the following procedure: a $2.0 \mathrm{~mL} \mathrm{dmf}$ solution containing $0.0811 \mathrm{~g}(0.150 \mathrm{mmol})$ of racemic Fenoprofen calcium salt hydrate $\left(\mathrm{Ca}(\mathrm{fen})_{2} \cdot \mathrm{H}_{2} \mathrm{O}\right)$ was added to $3.0 \mathrm{~mL}$ of an ethanolic solution of $\mathrm{CuCl}_{2} \cdot 2 \mathrm{H}_{2} \mathrm{O}(0.0170 \mathrm{~g}$, $0.100 \mathrm{mmol})$. The resulting green solution was stirred at room temperature for about one hour and then kept at the same temperature overnight. The addition of an excess of water led to the immediate precipitation of a green complex with a glassy appearence, which gradually recrystallized at room temperature after three weeks. The bright green microcrystals obtained were filtered, washed with water and air dried. Yield: $64 \%$ (0.0387g) Elemental analysis, found: $\mathrm{C}, 62.5 ; \mathrm{H}, 4.9 ; \mathrm{N}, 1.7 \%$. Calc. for $\mathrm{C}_{66} \mathrm{H}_{70} \mathrm{Cu}_{2} \mathrm{~N}_{2} \mathrm{O}_{16}$ : 
C, 62.2; H, 5.4; N, 2.1\%). A slow recrystallization of the complex in $\mathrm{dmf} /$ water yielded green single crystals without crystallization water which were studied by X-ray diffractometry. These results were published elsewhere. ${ }^{36}$

\section{Physical measurements}

Infrared spectra $\left(400-4000 \mathrm{~cm}^{-1}\right)$ were recorded on a Nicolet Nexus FTIR spectrophotometer with samples prepared as $\mathrm{KBr}$ pellets or Nujol mulls. UV-Vis spectra (190-900 nm) were registered on GBC-Cintra 20 equipment. Thermogravimetric (TGA) and differential thermal analysis (DTA) were carried out on a Shimadzu TGA-50H/DTA-50 thermal analyzer, under a nitrogen flow of $20 \mathrm{~cm}^{3} \mathrm{~min}^{-1}$ up to a final temperature of $850{ }^{\circ} \mathrm{C}$. The heating rate was $5{ }^{\circ} \mathrm{C} \mathrm{min}^{-1}$, and sample masses employed were about $6.0 \mathrm{mg}$. $\mathrm{Al}_{2} \mathrm{O}_{3}$ was used as the DTA reference standard. The EPR spectra of polycrystalline samples were obtained, at room temperature, with a Bruker ER200 spectrometer operating at $\mathrm{X}$ band $(\mathrm{ca} .9 .8 \mathrm{GHz})$, with a Bruker cavity and a modulation field of $100 \mathrm{kHz}$.

\section{Anti-inflammatory activity}

To evaluate the anti-inflammatory activity of the test compound, carrageenan-induced paw oedema assays were carried out as described by Winter et al. ${ }^{37}$ Female mice of about $30 \mathrm{~g}$ were randomly divided into three groups. Each group contained ten mice fasted for $18 \mathrm{~h}$. Test animals were administered orally an aqueous suspension of the copper(II) complex under study $\left(26 \mathrm{mg} \mathrm{kg}^{-1}\right)$ or the calcium salt of Fenoprofen $\left(22 \mathrm{mg} \mathrm{kg}^{-1}\right)$. Each quantity of drug administered is equivalent to $20 \mathrm{mg} \mathrm{kg}^{-1}$ of Fenoprofen. The vehicle alone was used as excipient for the control group. The drugs were suspended in carboxymethylcellulose at $0.1 \%$ and Tween 80 at $0.05 \%(1: 1, \mathrm{v} / \mathrm{v})$ just before use. To facilitate dissolution, the copper(II) complex was dissolved previously in dmf and the calcium salt of Fenoprofen in a $2 \%$ solution of bicarbonate, which were also given to the control group. Drug and excipient were orally administered ( $0.5 \mathrm{~mL}$ of the corresponding suspension to each animal) one hour before inducing oedema in the left hind paw by sub-plantar injection of $0.05 \mathrm{~mL}$ of a $2 \%$ suspension of carrageenan.

The length of the paw was measured with a digital electronic caliber "Caliper" $(0.1 \mathrm{~mm}$ resolution $)$ immediately before the injection of carrageenan and 3, 5, 7 and $9 \mathrm{~h}$ after the injection. The anti-inflammatory effect of the test was expressed in terms of the percentage of inhibition of the oedema produced in each drug-treated group and was calculated as $[(\Delta \mathrm{C}-\Delta \mathrm{T}) / \Delta \mathrm{C}] \times 100$, being $\Delta \mathrm{C}$ the mean of the control group and $\Delta \mathrm{T}$ the mean of the test group. The data were expressed as mean \pm SEM (standard error of the mean).

In order to determine the significant differences between the mean response of each treated group and the control group, Student's $t$ test has been applied. The difference in the average response of the group treated with the complex and the one treated with the Fenoprofen calcium salt was also determined. Statistical significance was set as $\mathrm{P}<0.01$.

\section{Kinetic assays}

Kinetic experiments concerning the oxidation of 3,5-di-tert-butylcatechol (3,5-dtbc) were monitored spectrophotometrically by following the increase of the 3,5-di-tert-butyl-o-benzoquinone (3,5-dtbq) characteristic absorption band at $400 \mathrm{~nm}$. Data of thermostated solutions $\left(25.0 \pm 0.5^{\circ} \mathrm{C}\right)$ were collected over $10 \mathrm{~min}$. The experiment was carried out by the addition of $1.50 \mathrm{~mL}$ of a freshly prepared (3,5-dtbc) solution in methanol $(0.25,0.50,1.0$, 2.0, 4.0, 6.0, 8.0, $\left.10.0 \times 10^{-3} \mathrm{~mol} \mathrm{~L}^{-1}\right)$ to a 1-cm-path-lengh cell containing $1.50 \mathrm{~mL}$ of a methanol solution of the copper complex $\left(5.00 \times 10^{-5} \mathrm{~mol} \mathrm{~L}^{-1}\right)$. During the kinetic run, the reaction cell was not covered to allow the solution to be continually equilibrated to atmospheric oxygen. The mean value of three experiments was determined using a methanolic solution of the substrate without the complex as a blank. Reaction rates were calculated from $\varepsilon=1900 \mathrm{~L}$ $\mathrm{mol}^{-1} \mathrm{~cm}^{-1}$ for 3,5-dtbq in methanol. ${ }^{20}$ The initial reaction rates were obtained from the slope of the 3,5-dtbq molar concentration versus time plots performed with a potential function regression. The same treatment was applied to a methanolic solution of $\mathrm{CuCl}_{2}$ in order to obtain the same final copper(II) concentration of the complex solution, and to evaluate the catecholase activity of free cupric ions.

A kinetic treatment of the experimental data revealed a saturation Michaelis-type mechanism for the reaction and then the Michaelis-Menten approach was applied using commercially available software.

\section{Results and Discussion}

\section{Spectroscopic characterizations of $\left[\mathrm{Cu}_{2}(\mathrm{fen})_{4}(\mathrm{dmf})_{2}\right]$}

The FTIR spectra of the solid $\mathrm{Ca}(\mathrm{fen})_{2} \cdot \mathrm{H}_{2} \mathrm{O}$ and the microcrystalline copper complex show bands assignable to the asymmetric and symmetric stretching vibrations of the fenoprofenate anion, $v_{\text {asym }}(\mathrm{COO})$ and $v_{\text {sym }}(\mathrm{COO})$, moving from 1560 and $1420 \mathrm{~cm}^{-1}$ on the calcium salt to 1614 and $1408 \mathrm{~cm}^{-1}$, respectively, on the copper(II) complex. These shifts, notwithstanding the observed wavenumber 
difference for the copper complex $\left(\Delta=206 \mathrm{~cm}^{-1}\right)$, correspond to the bridging coordination form of the anions observed in the crystal structure of the dinuclear copper(II) complex. ${ }^{36}$ These results are comparable to those observed for other dinuclear copper(II) carboxylate complexes with NSAIDs. ${ }^{30,38,39} \mathrm{~A}$ band located at $1668 \mathrm{~cm}^{-1}$ in the copper complex spectrum corresponds to the $v(\mathrm{C}=\mathrm{O})$ vibration of the $\mathrm{dmf}$ molecules, red-shifted against the free solvent $\left(1684 \mathrm{~cm}^{-1}\right),{ }^{40}$ assuring its coordination to the copper atoms. The vibrational spectra of the compounds are included into the Supplementary Information, SI (Figure S1). The broad and medium intensity band located at $c a .3460 \mathrm{~cm}^{-1}$ in the Nujol mull spectrum of the microcrystalline copper(II) complex was assigned to the stretching vibrations of the solvating (water) molecules in the crystal.

The EPR spectra of the microcrystalline $\left[\mathrm{Cu}_{2}(\mathrm{fen})_{4}(\mathrm{dmf})_{2}\right] \cdot 2 \mathrm{H}_{2} \mathrm{O}$ complex resemble the spectra of many other ligand-bridged dinuclear copper(II) complexes with paddle wheel " $\{\text { copper(II) }\}_{2}$ (carboxylate)" cages wherein the zero field splitting (D) is significantly greater than $h \vee$ and $\mathrm{E} \cong 0$ (axial symmetry). ${ }^{41-43}$ A representative EPR spectrum of the fenoprofenate-copper complex recorded at room temperature is shown in Figure 1. If the two copper(II) ions are in a moderate interaction, the ground state of the dicupric center is a singlet $(S=0)$ and the triplet state $(S=1)$ can be thermally populated. Thus we expect to observe a spectrum with a half-field transition $(\Delta \mathrm{Ms}= \pm 2)$ at $c a .1600 \mathrm{G}$ at room temperature and three lines, corresponding to resonance fields $\mathrm{Hz}_{1}, \mathrm{H}_{\perp}$, and $\mathrm{Hz}_{2}$, of the six $\Delta M= \pm 1$ resonance fields..$^{41}$ The peaks observed at 502, 4590 and $6080 \mathrm{G}$ are attributed to $\mathrm{Hz}_{1}, \mathrm{H}_{\perp}$ and $\mathrm{Hz}_{2}$, respectively, according to early reports in similar copper(II) dinuclear complexes. ${ }^{41,42} \mathrm{~A}$ small signal corresponding to mononuclear impurity is also observed. The quality of the spectrum precludes a precise determination of the magnetic parameters of the complex. Using a zero field splitting from literature data ${ }^{44}\left(\mathrm{D}=-150 \mathrm{~cm}^{-1}\right)$ and with the equipment set at a frequency of $9.76 \mathrm{GHz}$, the calculated magnetic parameters obtained are: $\mathrm{g}_{\perp}=2.14$ and $\mathrm{g}_{\mathrm{z}}=2.49$, similar to the values reported for other dicopper(II)-tatracarboxylate complexes. ${ }^{45,46}$

Regarding the thermal behavior of selected samples (single crystals) of the $\left[\mathrm{Cu}_{2}(\mathrm{fen})_{4}(\mathrm{dmf})_{2}\right]$ complex, the first mass loss step in the thermogravimetric analysis was observed between 59 and $196^{\circ} \mathrm{C}$, accompanied by a weak endothermic DTA signal at $100^{\circ} \mathrm{C}$ (Table 1 and Figure S2). The observed value of $11.6 \%$ is in agreement with the theoretical mass loss of $11.80 \%$ calculated for the elimination of both dmf molecules. A second event (step II) of $52.4 \%$ mass loss may correspond to the decomposition of the diphenyleter radical, calculated as $52.72 \%$ of the

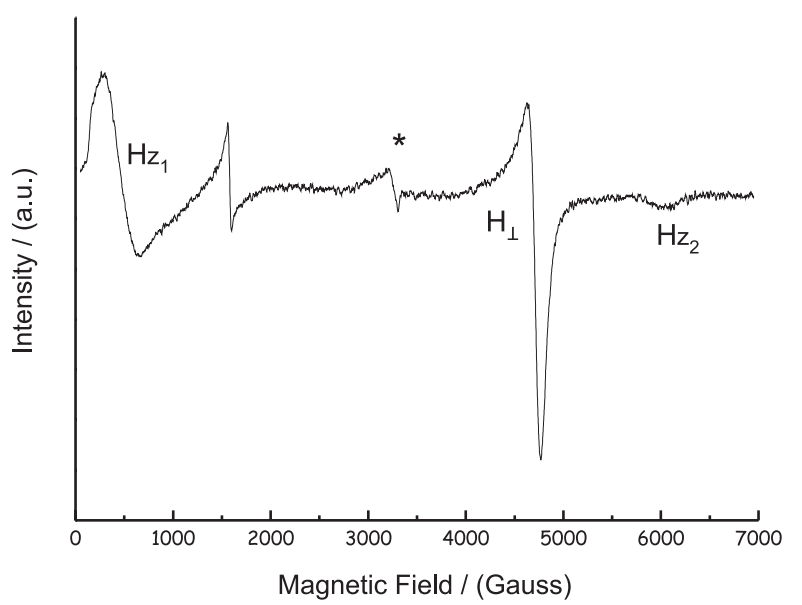

Figure 1. X-band EPR spectrum of microcrystalline $\left[\mathrm{Cu}_{2}(\mathrm{fen})_{4}(\mathrm{dmf})_{2}\right] \cdot 2 \mathrm{H}_{2} \mathrm{O}$ at $298 \mathrm{~K}$. The asterisk $(*)$ indicates the signal due to a monomeric impurity.

total molar mass. In the last step (step III) an exothermic process occurs, which involves the final decomposition of the substance with concomitant $\mathrm{CuO}$ formation. The total mass loss observed $(85.0 \%)$ is in good agreement with the theoretical mass loss calculated as $87.17 \%$.

Table 1. Thermal stability analysis (TGA and DTA) of single crystals of $\left[\mathrm{Cu}_{2}(\mathrm{fen})_{4}(\mathrm{dmf})_{2}\right]$

\begin{tabular}{lcccc}
\hline Step & $\begin{array}{c}\text { Temperature } \\
\text { range }\left({ }^{\circ} \mathrm{C}\right)\end{array}$ & \multicolumn{2}{c}{ TGA (mass loss, \%) } & DTA $\left({ }^{\circ} \mathrm{C}\right.$, heat \\
Obs. & Calc. & flux, intensity) \\
\hline I & $59-196$ & 11.6 & 11.80 & 100 , endo, weak \\
II & $196-330$ & 52.4 & 52.72 & $217 / 270$, endo, weak \\
III & $330-552$ & 21.0 & 22.65 & 539, exo, strong \\
\hline
\end{tabular}

The electronic spectra recorded in a Nujol mull for the microcrystalline Fenoprofen-copper(II) complex exhibit one broad asymmetric band centred at $699 \mathrm{~nm}$ (Table 2). This band, observed in the UV-vis spectra of binuclear copper(II) carboxylate complexes (usually named Band I), is assignable to the $\mathrm{d}$ - $\mathrm{d}$ transitions of tetragonally distorted copper(II) centres. ${ }^{47}$ It changes slightly to $705 \mathrm{~nm}$ in dmf solutions. In methanol solutions this d-d band moves to $694 \mathrm{~nm}$, without changes in the absorptivity. A second absorption band (currently named Band II) is observed at $370 \mathrm{~nm}$ in dmf solutions and is characteristic of the bridging rather than the coppercopper linkage in dinuclear copper complexes. ${ }^{46,47}$ In the spectrum of the complex in methanol solutions this band is absent, indicating an important degree of dissociation of the dinuclear structure. ${ }^{48}$ For dinuclear copper tetracarboxylates a third band assignable to a carboxylcopper(II) charge transfer absorption is expected around $290 \mathrm{~nm} .{ }^{47}$ In the complex under study it is masked by the strong intraligand fenoprofenate absorptions. 
Table 2. Assignments of characteristic electronic absorption bands of $\mathrm{Ca}(\mathrm{fen})_{2} \cdot \mathrm{H}_{2} \mathrm{O}$ and $\left[\mathrm{Cu}_{2}(\mathrm{fen})_{4}(\mathrm{dmf})_{2}\right] \cdot 2 \mathrm{H}_{2} \mathrm{O}$

\begin{tabular}{|c|c|c|c|}
\hline \multirow[t]{2}{*}{ Media } & \multicolumn{2}{|c|}{ UV-Vis bands $(\mathrm{nm}) / \varepsilon\left(\mathrm{L} \mathrm{mol}^{-1} \mathrm{~cm}^{-1}\right)$} & \multirow[t]{2}{*}{ Assignment } \\
\hline & {$\left[\mathrm{Cu}_{2}(\text { fen })_{4}(\mathrm{dmf})_{2}\right] \cdot 2 \mathrm{H}_{2} \mathrm{O}$} & $\mathrm{Ca}(\text { fen })_{2} \cdot \mathrm{H}_{2} \mathrm{O}$ & \\
\hline Nujol & 699 & ------ & $\mathrm{d} \rightarrow \mathrm{d}(\text { Band } \mathrm{I})^{\#}$ \\
\hline $\mathrm{dmf}$ & $\begin{array}{l}705 / 424 \\
370 / \mathrm{sh}\end{array}$ & ----- & $\begin{array}{l}\mathrm{d} \rightarrow \mathrm{d}(\text { Band I })^{\#} \\
\quad(\text { Band II })^{\#}\end{array}$ \\
\hline $\mathrm{MeOH}$ & $\begin{array}{c}694 / 410 \\
205 / 12480\end{array}$ & $218 / 11200$ & $\begin{array}{c}\mathrm{d} \rightarrow \mathrm{d} \\
\pi \rightarrow \pi^{*}(\text { phenoxy rings })\end{array}$ \\
\hline
\end{tabular}

\# See text for assignment.

\section{Anti-inflammatory activity}

Figure 2 summarizes the anti-inflammatory activity of microcrystalline $\left[\mathrm{Cu}_{2}(\mathrm{fen})_{4}(\mathrm{dmf})_{2}\right] \cdot 2 \mathrm{H}_{2} \mathrm{O}$ and Fenoprofen calcium salt in mice paw carrageenan-induced oedema. The results are presented as means \pm standard error (SEM) for the inflammation grade approached in each group.

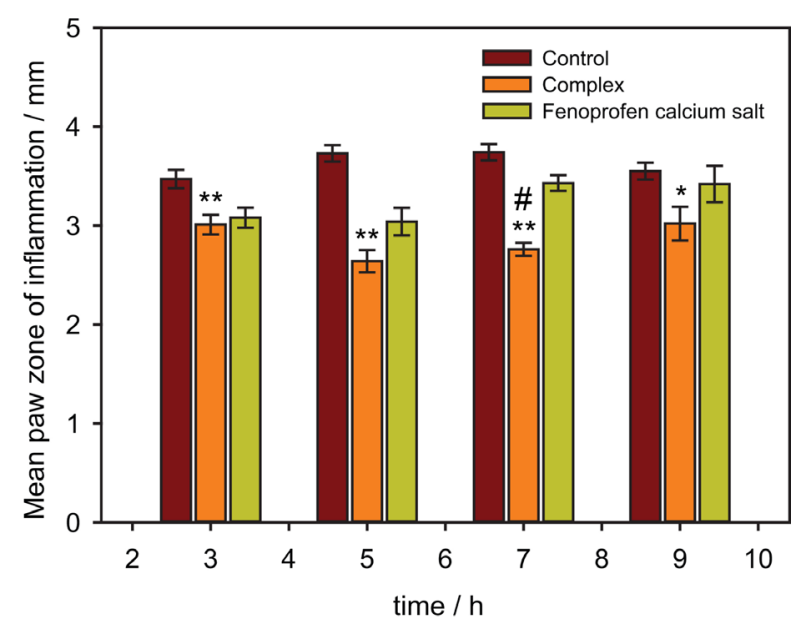

Figure 2. Inflammation grade approached in carrageenan-induced paw oedema in mice. $* \mathrm{P}<0.05$ for complex vs. control; $* * \mathrm{P}<0.01$ for complex vs. control; \# $\mathrm{P}<0.01$ for complex vs. Fenoprofen calcium salt. Student's $t$ test was applied for the statistical analysis.

The study of the acute anti-inflammatory test showed that the Fenoprofen-copper(II) complex produces a very significant reduction in carrageenan-induced paw oedema when compared to the control group $(\mathrm{P}<0.01)$ at 3,5 and $7 \mathrm{~h}$, as well as a significant reduction at $9 \mathrm{~h}$ after the injection of carrageenan. It also presented enhanced antiinflammatory activity with respect to the uncomplexed parent drug. It is remarkable the fact that the complex presented a great significant difference $(\mathrm{P}<0.01)$ in the anti-inflammatory properties at the seventh hour of the experiment when compared to the Fenoprofen calcium salt; this fact indicates that the complex presents a more sustained anti-inflammatory action in time.

Figure 3 shows the inflammation inhibition percentage attained in the experiments. Analyzing the results over time, it can be seen that at the third hour there were no differences between the action of the Fenoprofen calcium salt and the copper(II)-Fenoprofen complex (29 and $28 \%$ respectively). However, in the following hours until the end of the experiment, the complex inhibited the inflammation caused by the carrageenan-induced paw oedema with more efficiency than the uncomplexed parent drug. After $5 \mathrm{~h}$ of carrageenan injection, the percentage inhibition of inflammation by calcium fenoprofenate was $42 \%$, whereas with the copper(II) complex was $60 \%$. When the calcium salt approached $20 \%$ of inhibition at the seventh hour, the complex approached 50\%. Finally, $9 \mathrm{~h}$ after the injection of carrageenan, the Fenoprofen calcium salt inhibited the inflammation of the left hind paw on $10 \%$ meanwhile the percent inhibition for the complex was $31 \%$. These results show clearly that between the fifth and the seventh hour after the injection of carrageenan the decay of the anti-inflammatory action of the complex was very low and that along all the experiment this action was more efficient than that from the uncomplexed fenoprofenate anions.

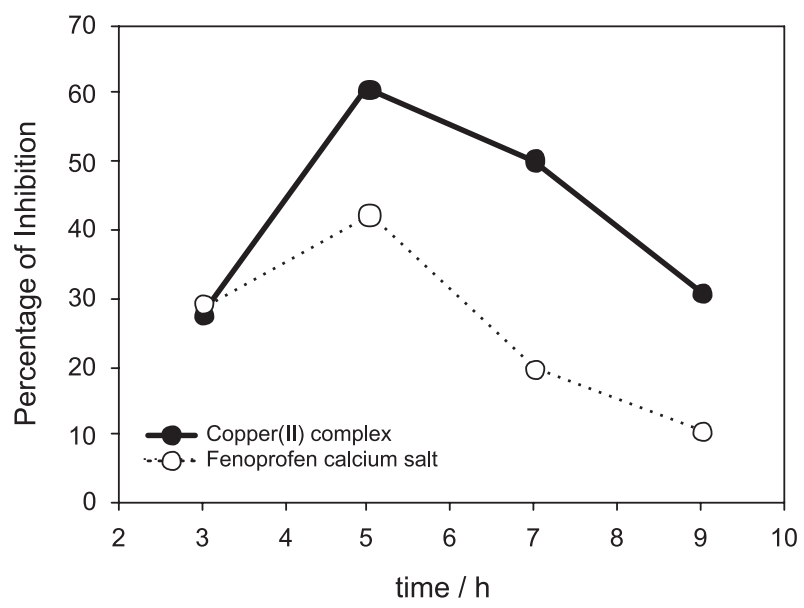

Figure 3. Percentage of inhibition vs. time in carrageenan-induced paw oedema in mice.

All these data indicate that the copper complex presents enhanced anti-inflammatory properties and are in accordance to the behavior of other copper(II)-NSAIDs complexes. ${ }^{1,11}$ 


\section{Catecholase activity}

Before going to the detailed kinetic study, it was necessary to get an estimation of the ability of the complex to oxidize catechols. Commonly $3,5-\mathrm{dtbc}$ is used as a substrate due to its low redox potential and because the bulky tert-butyl groups prevent unwanted side reactions such as ring opening or polymerization of the resulting quinone. ${ }^{12,20}$ As a starting catalytic analysis a $2.50 \times 10^{-5} \mathrm{~mol} \mathrm{~L}^{-1}$ solution of the copper complex was allowed to react with a $2.50 \times 10^{-3} \mathrm{~mol} \mathrm{~L}^{-1}$ solution of 3,5-dtbc under aerobic conditions and the course of the reaction was followed by UV-Vis spectroscopy. The UVVis spectra were recorded immediately after the addition of the substrate and then after 5, 10, 20, 30 and $60 \mathrm{~min}$ and they were corrected with the blank solution composed by solvent (methanol) and 3,5-dtbc. The increase in the absorption at $400 \mathrm{~nm}$ showed moderate catecholase activity (turnover around 6.8 at $10 \mathrm{~min}$ ) for the Fenoprofenatecopper complex (Figure 4).

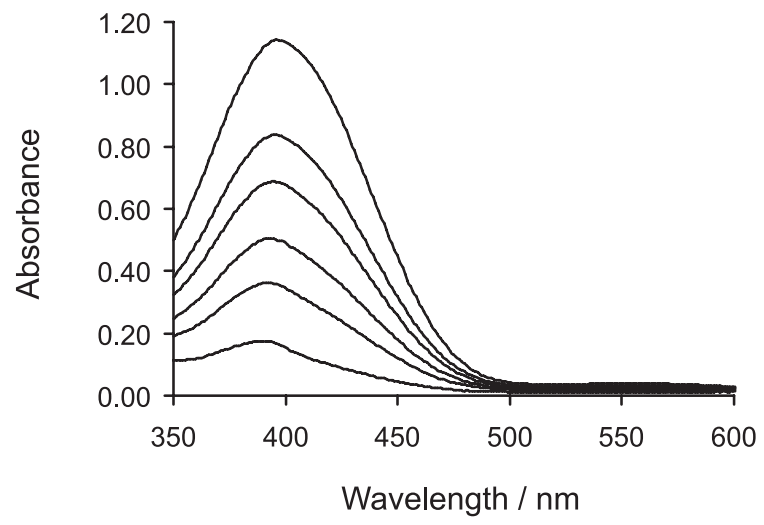

Figure 4. Increase of the 3,5-dtbq absorption band at $400 \mathrm{~nm}$ after addition of 3,5 -dtbc $\left(2.50 \times 10^{-3} \mathrm{mmol} \mathrm{L}^{-1}\right)$ to a solution of the copper(II) fenoprofenate complex $\left(2.50 \times 10^{-5} \mathrm{mmol} \mathrm{L}^{-1}\right)$ in methanol. The spectra were recorded at the beginning of reaction and after 5, 10, 20, 30, $60 \mathrm{~min}$.

The 3,5-dtbq concentration $v s$. time plots (Figure S3) were fitted with potential functions in order to recover the initial reaction rates $\left(\mathrm{V}_{0}\right)$. The dependence of $\mathrm{V}_{0}$ on the 3,5$\mathrm{dtbc}$ concentrations for the oxidation reaction catalyzed by the dicopper(II) complex (Figure 5) and the correlation between $\mathrm{V}_{0}^{-1}$ and $[3,5-\mathrm{dtbq}]^{-1}$ (Figure S4) both indicate the existence of a two step Michaelis type mechanism for the reaction. ${ }^{49}$ Then a complete kinetic study was carried out on the basis of the Michaelis-Menten (M-M) model originally developed for enzymatic reactions. The good accordance of data with the model indicates the existence of a complexation equilibrium between the dtbc substrate and the active copper(II) species in the methanol solution. The obtained M-M parameters were: $\mathrm{K}_{\mathrm{M}}=(0.133 \pm$
$0.023) \times 10^{-3} \mathrm{~mol} \mathrm{~L}^{-1}$ and $\mathrm{V}_{\text {max }}=(5.70 \pm 0.16) \times 10^{-5} \mathrm{~mol} \mathrm{~L}^{-1}$ $\mathrm{min}^{-1}$. The dominant active copper(II) species present in the methanolic solution, possibly a mononuclear complex as demonstrated by the information provided by the UV-Vis spectra discussed above, presents a good affinity for the substrate 3,5-dtbc as evidenced by the $\mathrm{K}_{\mathrm{M}}$ value.

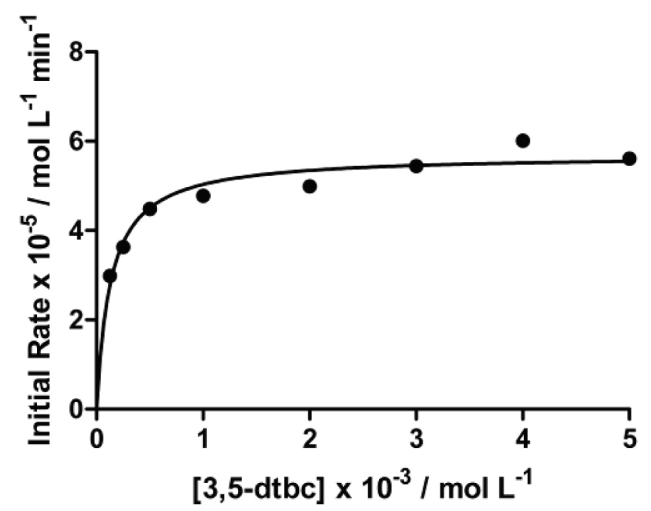

Figure 5. Initial rate of the oxidation of 3,5-dtbc to 3,5-dtbq $v s$. substrate concentration in the presence of $2.50 \times 10^{-5} \mathrm{mmol} \mathrm{L}^{-1}$ of the microcrystalline copper fenoprofenate complex in methanol at $25.0 \pm 0.5^{\circ} \mathrm{C}$.

When methanolic solutions of $\mathrm{CuCl}_{2}$ were tested $v s$. the 3,5-dtbc substrate under the same conditions employed for the complex under study, there was no significant catecholase mimetic activity for the solvated copper(II) ions (Figure S5). Hence, although the active species was not identified, the coordination of fenoprofenate anion to cupric ions in methanolic solution has been demonstrated.

By comparison with other mononuclear or dinuclear copper catecholase model complexes ${ }^{13-15,50}$ the copper(II) fenoprofenate shows moderate catecholase activity. It is necessary to take into account that comparisons are not always straightforward because of the use of different solvents, temperatures and degrees of solvent oxygenation.

\section{Conclusions}

A dinuclear copper(II) complex of Fenoprofen has been synthesized and characterized. Its physical and chemical properties are in good agreement with its dinuclear crystalline structure. The comparative study of inhibition of paw oedema by the copper(II) complex and the parent drug (Fenoprofen calcium salt) shows that there was a significant increase in antiinflammatory activity when the drug was given orally as the copper complex as compared to the drug itself. The kinetic characterization as a catechol oxidase mimetic demonstrates that the copper(II) fenoprofenate presents moderate catecholase activity. 


\section{Supplementary Information}

Supplementary information data (Figures S1-S5) are available free of charge at http://jbcs.sbq.org.br, as a PDF file.

\section{Acknowledgments}

M. A. A and O. V. Q thank SGCyT-UNS for financial support (Project 24/Q025). M. A. A is a fellow of CONICET (Consejo Nacional de Investigaciones Científicas y Técnicas). The authors are thankful to Alejandra Minetti, Fernanda Gumilar and Cristina Bras for their help in the statistical studies. The authors would also like to thank Dr. Carlos Brondino (Departamento de Física, FBCB-UNL, Santa Fe, Argentina) and Dr. José Pedregosa (Facultad de Química, Bioquímica y Farmacia, UNSL, San Luis, Argentina) for kindly registering the EPR spectra and carrying out the TGA/DTA analyses, respectively, of the copper complex.

\section{References}

1. Weder, J. E.; Dillon, C. T.; Hambley, T. W.; Kennedy, B. J.; Lay, P. A.; Biffin, J. R.; Regtop, H. L.; Davies, N. M.; Coord. Chem. Rev. 2002, 232, 95.

2. De Souza, R. L.; Tubino, M.; J. Braz. Chem. Soc. 2005, 16, 1068.

3. Milanino, R.; Conforti, A.; Franco, L.; Marella, M.; Velo, G. P.; Agents Actions 1985, 16, 504.

4. Roch-Arveiller, M.; Pham-Huy, D.; Mamam, L.; Giroud, J. P.; Sorenson, J. R. J.; Biochem. Pharm. 1990, 39, 569.

5. Silverio Amancio, O. M.; Alves Chaud, D. M.; Yanaguibashi, G.; Esteves Hilario, M. O.; Eur. J. Clin. Nutr. 2003, 57, 706.

6. Sorenson, J. R. J.; Prog. Med. Chem. 1989, 26, 437.

7. Sorenson, J. R. J.; Chem. Brit. 1984, 20, 1110.

8. Sorenson, J. R. J.; Kishore, V.; Pezeshk, A.; Oberley, L. W.; Leuthauser, S. W. C.; Inorg. Chim. Acta 1984, 91, 285.

9. Rainsford, K. D.; Whitehouse, M. W.; J. Pharm. Pharmacol. 1976, 28, 83.

10. Oga, S.; Taniguchi, S. F.; Najjar, R.; Souza, A. R.; J. Inorg. Biochem. 2001, 41, 45.

11. Henderson, W. R.; Ann. Intern. Med. 1994, 121, 684.

12. Ackermann, J.; Buchler, S.; Meyer, F.; C. R. Chim. 2007, 10, 421.

13. Ackermann, J.; Meyer, F.; Kaifer, E.; Pritzkow, H.; Chem. Eur. J. 2002, 8, 247.

14. Gentschev, P.; Möller, N.; Krebs, B.; Inorg. Chim. Acta 2000, 300-302, 442.

15. Yang, C. T.; Vetrichelvan, M.; Yang, X.; Moubaraki, B.; Murray, K. S.; Vittal, J. J.; J. Chem. Soc., Dalton. Trans. 2003, 113.

16. Krebs, B. In Bioinorganic Chemistry - An Inorganic Perspective of Life; Kessissoglou, D. P., ed.; Kluwer Acad. Pub.: Dordrecht, 1995, p. 359.
17. Salvato, B.; Santamaria, M.; Beltramini, M.; Alzuet, G.; Casella, L.; Biochemistry 1998, 37, 14065.

18. Fernandes, S. C.; de Barros Osorio, R. E. M.; dos Anjos, A.; Neves, A.; Micke, G. A., Vieira, I. C.; J. Braz. Chem. Soc. 2008, 19,1215 .

19. Neves, A.; Rossi, L. M.; Bortoluzzi, A. J.; Szpoganicz, B.; Wiezbicki, C.; Schwingel, E.; Inorg. Chem. 2002, 41, 1788.

20. Neves, A.; Rossi, L. M.; Bortoluzzi, A. J.; Mangrich, A. S.; Haase, W.; Werner, R.; J. Braz. Chem. Soc. 2001, 12, 747.

21. Gasque, L.; Ugalde-Saldivar, V. M.; Membrillo, I.; Olguín, J.; Mijangos, E.; Bernès, S.; Gonzalez, I.; J. Inorg. Biochem. 2008, 102, 1227.

22. Smith, S. J.; Noble, C. J.; Palmer, R. C.; Hanson, G. R.; Schenk, G.; Gahan, L. R.; Riley, M. J.; J. Biol. Inorg. Chem. 2008, 13, 499.

23. Malachowski, M. R.; Dorsey, B. T.; Parker, M. J.; Adams, M. E.; Kelly, R. S.; Polyhedron 1998, 17, 1289.

24. Malachowski, M. R.; Huynh, H. B.; Tomlinson, L. J.; Kelly, R. S.; Jun, J. W. F.; J. Chem. Soc., Dalton Trans. 1995, 31.

25. Monzani, E.; Battaini, G.; Perotti, A.; Casella, L.; Gullotti, M.; Santagostini, L.; Nardin, G.; Randaccio, L.; Geremia, S.; Zanello, P.; Opromolla, G.; Inorg. Chem. 1999, 38, 5359.

26. Monzani, E.; Quinti, L.; Perotti, A.; Casella, L.; Gullotti, M.; Randaccio, L.; Geremia, S.; Nardin, G.; Faleschini, P.; Tabbi, G.; Inorg. Chem. 1998, 37, 553.

27. Lee, C-H.; Wang, S. T.; Lin, T-S.; Mou, C-Y.; J. Phys. Chem. B 2005, 109, 775.

28. Selmeczi, K.; Réglier, M.; Giorgi, M.; Speier, G.; Coord. Chem. Rev. 2003, 245, 191.

29. Oishi, N.; Nishida, Y.; Ida, K.; Kida, S.; Bull. Chem. Soc. Jpn. 1980, 53, 2847.

30. Abuhijleh, A. L.; J. Inorg. Biochem. 1994, 55, 255.

31. Abuhijleh, A. L.; Woods, C.; Inorg. Chim. Acta 1993, 209, 187.

32. Abuhijleh, A. L.; Woods, C.; Bogas, E.; Le Guenniou, G.; Inorg. Chim. Acta 1992, 195, 67.

33. Nickander, R.; Marshall, W.; Emmerson, J. L.; Todd, G. C. In Pharmacological and Biochemical Properties of Drug Substances; Goldberg, M. E., ed.; Am. Pharm. Assoc.: Washington, 1977, pp. 183-213.

34. Stephenson, G. A.; Diseroad, B. A.; Int. J. Pharm. 2000, 198, 167.

35. Zhu, H.; Xu, J.; Varlashkin, P.; Long, S.; Kidd, C.; J. Pharm. Sci. 2001, 90, 845.

36. Agotegaray, M. A.; Quinzani, O. V.; Faccio, R.; Goyenola, C.; Mombrú, A. W.; Acta Crystallogr. E 2008, 64, 1612.

37. Winter, C. A.; Risley, E. A.; Nuss, G.; Proc. Soc. Exp. Biol. Med. 1962, 111, 544.

38. Viossat, B.; Greenaway, F. T.; Morgant., G.; Daran, J.-C.; Dung, N.-H.; Sorenson, J. R. J.; J. Inorg. Biochem. 2005, 99, 355.

39. Weder, J. E.; Hambley, T. W.; Kennedy, B. J.; Lay, P. A.; MacLachlan, D.; Bramley, R.; Delfs, C. D.; Murray, K. S.; Moubaraki, B.; Warwick, B.; Biffin, J. R.; Regtop, H. L.; Inorg. Chem. 1999, 38, 1736. 
40. Durgaprasad, G.; Sathyanarayana, D. N.; Patel, C. C.; Bull. Chem. Soc. Jpn. 1971, 44, 316.

41. Mosae Selvakumar, P.; Suresh, E.; Subramanian, P. S.; Inorg. Chim. Acta 2008, 361, 1503.

42. Wasson, J. R.; Shyr, C. I.; Trapp, C.; Inorg. Chem. 1968, 7, 469.

43. Abe, H.; Shimada, J.; Phys. Rev. 1953, 90.

44. Perec, M.; Baggio, R.; Sartoris, R. P.; Santana, R. C.; Peña, O.; Calvo, R.; Inorg. Chem. 2010, 49, 695.

45. Muto, Y.; Nakashima, M.; Tokii, T.; Suzuki, I.; Ohba, S.; Steward, O. W.; Kato, M.; Bull. Chem. Soc. Jpn. 2002, 75, 511.
46. Meier, J. L.; Coughenor, C. E.; Carlisle, J. A.; Carlisle, G. O.; Inorg. Chim. Acta 1985, 106, 159.

47. Lever, A. B. P.; Inorganic Electronic Spectroscopy, $2^{\text {nd }}$ ed., Elsevier: New York, 1984.

48. Kumar, N.; Suri, A. K.; Proc. Indian Natl. Sci. Acad. 1980, 46A, 565.

49. Schmid, R.; Sapunov, V. N.; Non Formal Kinetics, Verlag Chemie: Weinheim, 1982, pp. 39-44.

50. Smith, S. J.; Noble, C. J.; Palmer, R. C.; Hanson, G. R.; Schenk, G.; Gahan, L. R.; Riley, M. J.; J. Biol. Inorg. Chem. 2008, 13, 499. 


\title{
Significant Anti-Inflammatory Properties of a Copper(II) Fenoprofenate Complex Compared with its Parent Drug. Physical and Chemical Characterization of the Complex
}

\author{
Mariela A. Agotegaray, ${ }^{a}$ Mónica A. Boeris ${ }^{b}$ and Oscar V. Quinzani*,a \\ ${ }^{a}$ INQUISUR, Departamento de Química, Universidad Nacional del Sur, Avda. Alem 1253, \\ B8000CPB Bahía Blanca, Argentina \\ ${ }^{b}$ Centro de Investigación y Desarrollo de Fármacos (CIDEF), Facultad de Ciencias Veterinarias, \\ Universidad Nacional de La Pampa, Calle 5 y 116, General Pico, CP 6360, Argentina
}

A

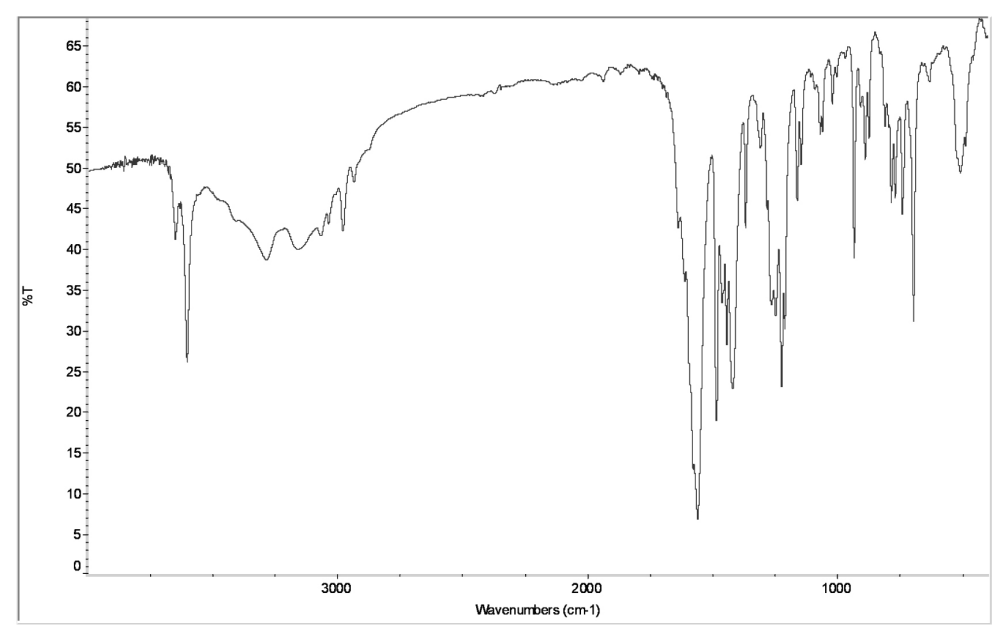

B

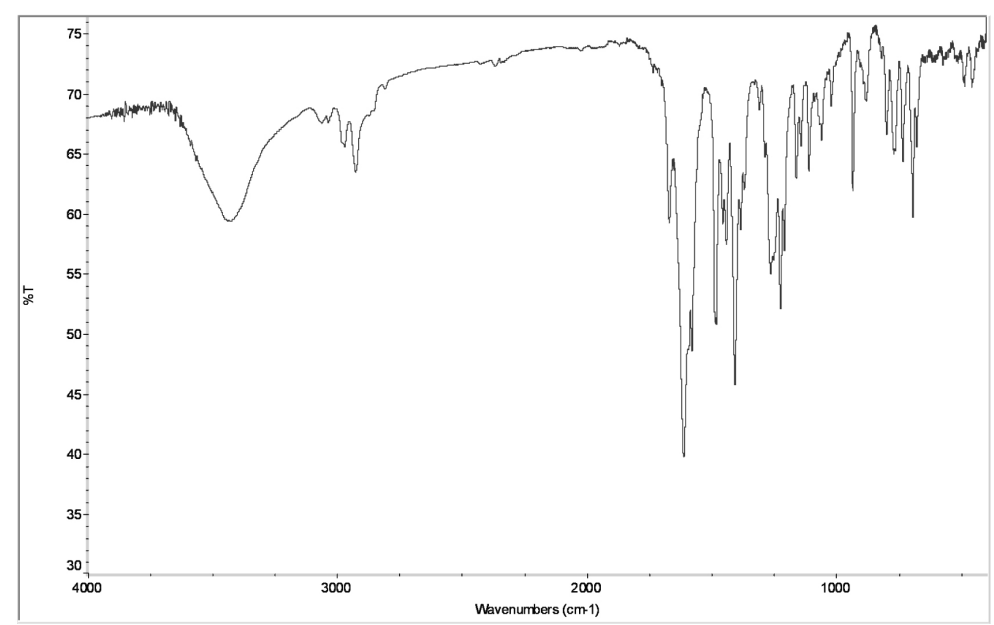

Figure S1. IR spectra of $\mathrm{KBr}$ dispersions of $\left[\mathrm{Ca}(\mathrm{fen})_{2}\right] \cdot \mathrm{H}_{2} \mathrm{O}(\mathrm{A})$ and microcrystalline $\left[\mathrm{Cu}_{2}(\mathrm{fen})_{4}(\mathrm{dmf})_{2}\right] \cdot 2 \mathrm{H}_{2} \mathrm{O}(\mathrm{B})$. 
A
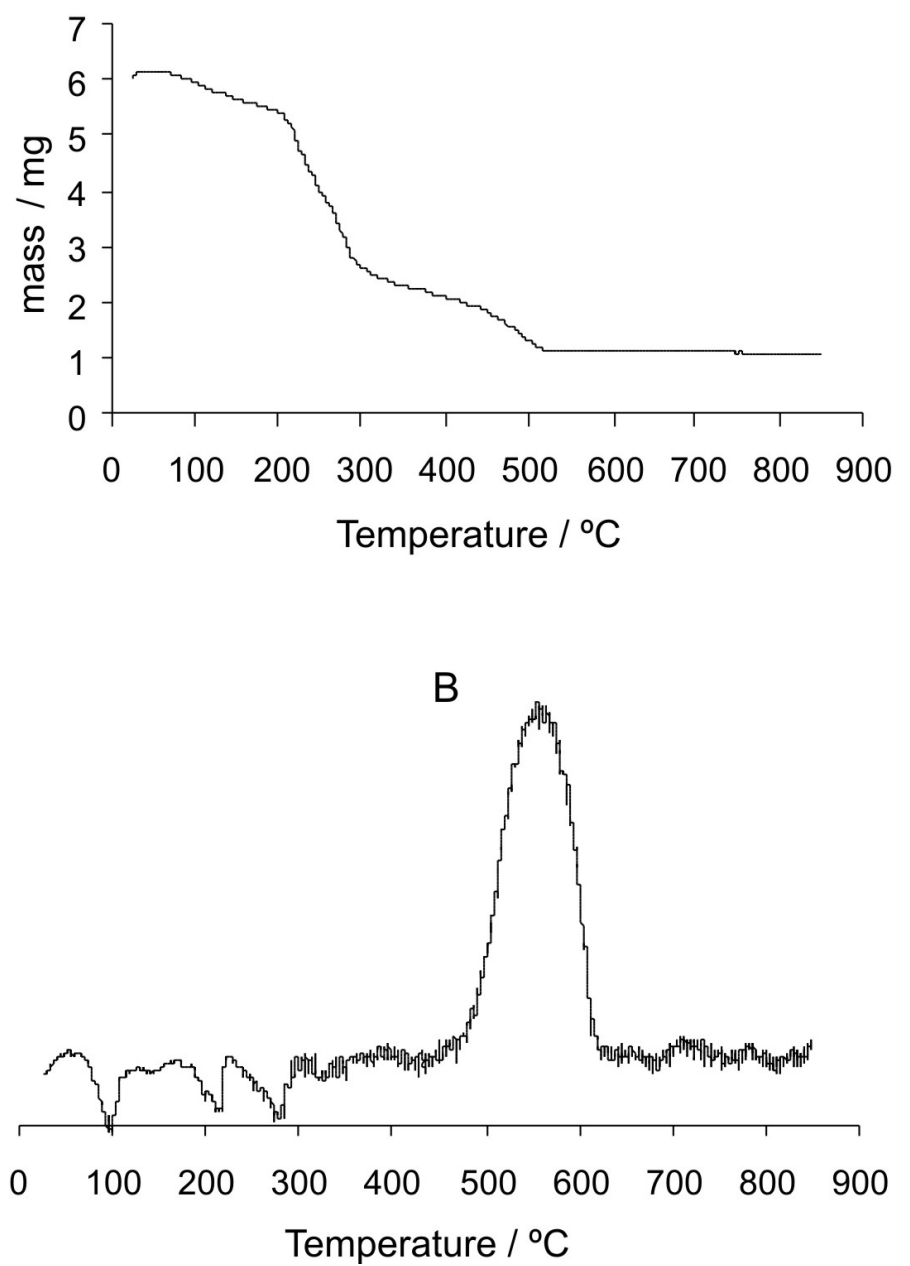

Figure S2. TGA (A) and DTA (B) curves recorded for single crystals of $\left[\mathrm{Cu}_{2}(\mathrm{fen})_{4}(\mathrm{dmf})_{2}\right](6.0 \mathrm{mg})$ under $\mathrm{N}_{2}$ flux $\left(20 \mathrm{~cm}^{3} \mathrm{~min}^{-1}\right)$. Heating rate: $5^{\circ} \mathrm{C} \mathrm{min}^{-1}$.

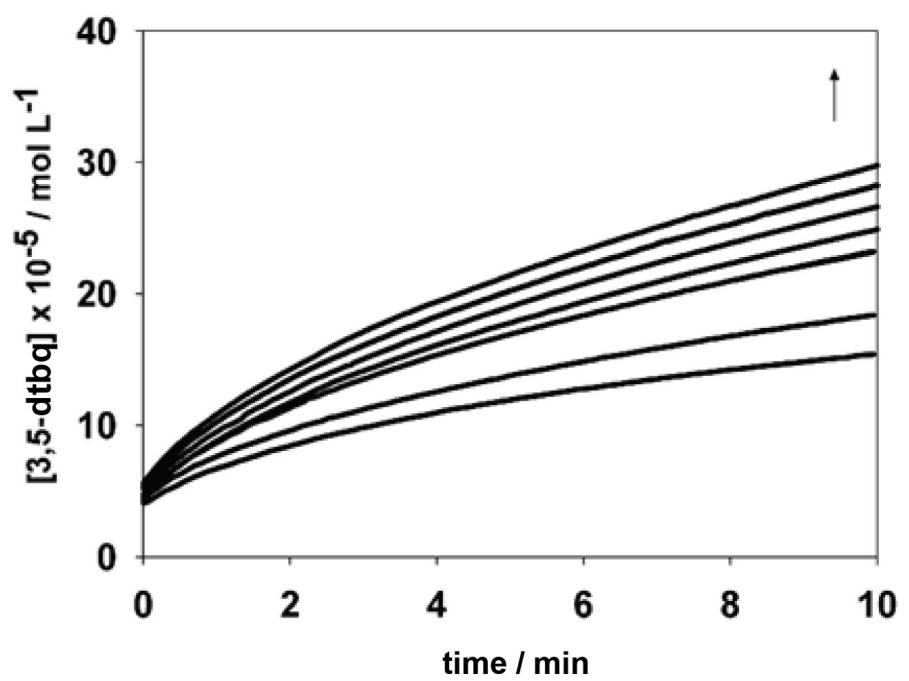

Figure S3. Variation of the 3,5-dtbq concentration $v s$. time. The up arrow indicates increasing concentrations of the substrate $(0.125 ; 0.25 ; 0.50 ; 1.0 ; 2.0$; $3.0 ; 4.0 ; 5.0 \mathrm{~mol} \mathrm{~L}-1)$. Copper(II) complex concentration: $2.50 \times 10^{-5} \mathrm{~mol} \mathrm{~L}^{-1}$. Temperature: $25.0 \pm 0.5^{\circ} \mathrm{C}$. 


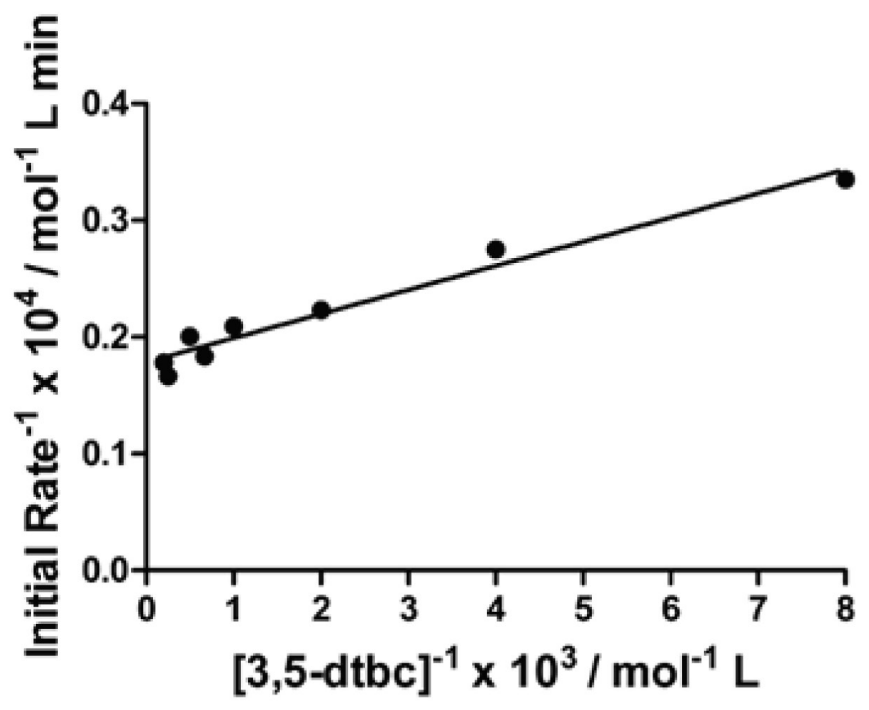

Figure S4. Lineweaver-Burk correlation plot for the catecholase mimetic activity of the copper(II) fenoprofenate complex in methanolic solution.

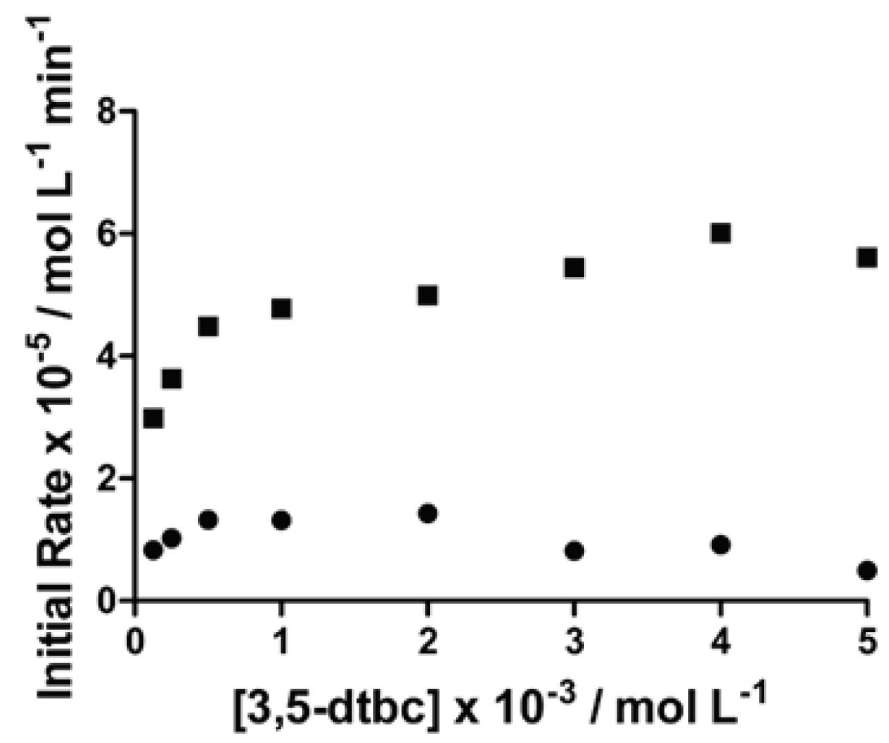

Figure S5. Comparative catecholase mimetic activity for the copper(II) fenoprofenate complex ( $\mathbf{\square})$ and free cupric ions (@) under the same experimental conditions. 